\title{
THE SETTLEMENT OF INDUSTRIAL DISPUTES IN GREAT BRITAIN
}

\author{
DoRothy Selzs* \\ "Trust in machinery as a substitute for specific kindliness \\ is one of the besetting sins of social reform." \\ -N. P. Gilman.
}

\section{The Nature of Industrial Disputes}

Strikes, like all disputes, result from conflict. Conflict arises out of clashing personal or party interests. In the industrial field the conflict occurs between the two parties to industry, those who work for profit and those who work for wages, or their agents. Given the existing economic system, superficial analysis suggests that industrial conflict must on this account continue ad infinitum. Both parties are working for money; what is accorded one in the nature of the case takes away from the other, therefore the conflict resolves itself into a struggle for purchasing power destined eternally to go on between those who supply stored up labor in the form of capital and those who furnish immediate labor by the sweat of their brows. Economic doctors taking this point of view customarily propose one of two solutions, on the one hand suppression of labor organizations and their activities with compulsory arbitration as a last resort, or unrelenting class war culminating in revolution, on the other.

But such a simple resolution of industrial conflict completely ignores several factors entering into a condition of conflict, most important of which is the human. Do both parties to industry work exclusively for purchasing power? Does not the fact that no worker can separate his person from his labor; that every "employer" has invested in his business possessions which he regards as peculiarly his own, create other conflictual issues revolving among workers about the desire for self-respecting conditions of work, recognition of self-organizations and self-determination in connection with their jobs; among employers about the desire to manage their own businesses without interference either from employees or from the government?

- B.A., 1916, Wellesley College; M.A., I917, University of Chicago; Ph.D., r923, University of London, School of Economics. Assistant Professor of Social Economy, Bryn Mawr College, 1924-28; Special Research, Industrial Disputes in Great Britain, National Labor Relations Board, 1934; Assistant Director, Consumer Purchasing Project, National Resources Committee, 1935; Research Associate, International Labor Organization, Washington Branch, 1935-38; at present on Temporary Staff, Brookings Institution, Washington, D. C. Author of The British Trade Boards System (P. S. King \& Son, Ltd., 1923), and of numerous articles on economic and other subjects. 
May not these issues result in a struggle for what may be termed psychologic power? Since employers and workers both derive their purchasing or economic power and their psychologic or personal power from the same industrial enterprise, should it not be possible on a basis of reason to find some means of satisfying these fundamental physical and psychologic needs of each party without at the same time destroying the source of their satisfaction? Conflict invariably being the result of opposing personal or party interests, should not the reverse of conflict which is cooperation in a common interest bigger than that of either person or party alone, provide the key to industrial peace? Through what instrument can industrial cooperation be achieved?

These constitute the leading practical questions emerging from a more profound analysis of industrial conflict in our modern society. And in answering such questions the experience of Great Britain extending over more than one hundred years appears at least to point the direction of attack.

\section{The Extent of Industrial Disputes in Great Britain}

A panorama of industrial relations in Great Britain reveals a series of conflict periods usually occurring in years of profound economic change, when the standard of living was threatened and organization of workers expanding. Such periods of severe conflict have frequently resulted in restrictive action of some sort. Passage of the Combination Acts in 1799 and 1800 following appeals to Parliament by artisans' clubs for protection against inroads upon their standard of living made by the Industrial Revolution represents the first action of this kind. After repeal of these laws in $1824-25$, a wave of strikes took place. Together with a financial crisis, this resulted -in further legislation restricting picketing and strikes until 1875 . By the terms of the Conspiracy and Protection of Property Act, 1875 , trade unions became free to do whatever a single individual might do in a trade dispute without subjection to criminal action. Thus, collective bargaining and the methods necessary to bring it about first became recognized at law after a half century of struggle.

Meanwhile trade union membership had greatly increased, a nine hour day for the major trades resulting. But a series of desperate strikes called in the midst of a severe trade depression soon undermined both union funds and memberships. The successful dock strike of 1889 gave fresh impetus to organization which was further encouraged by resentment at the Taff Vale decision of $1900^{1}$ rendering a trade union's funds liable for the tortious acts committed by its members or agents. A continuous climb in prices accompanied by abrogation of the Taff Vale decision through passage of the Trade Disputes Act, 1906, ${ }^{2}$ and political activity on the part of labor again led to bitter industrial conflict between rgro and rgr4. Various governmental tribunals assisted in maintaining industrial peace during the War period. But with wages lagging behind prices and a sudden slump another series of strikes broke out in the years rgrg to 1923. A brief cessation of industrial hostilities in 1924

${ }^{1}$ [Igor] A. C. $\$ 26$.

26 EDw. VII, c. 47. 
and 1925 culminated in a protracted stoppage in coal mining and the general strike of 1926 in which the aggregate time lost was considerably more than during the encire period from Ig05 to IgIg. The failure of this supreme effort by labor to dominate economic life, linked with a vivid realization by employers of labor's potential power, the enactment of the Trade Disputes and Trade Unions Act, $1927,{ }^{3}$ limiting the right to strike, and the onset of a strongly deflationary movement served during the next decade to throw employers and workers back upon the elaborate collective bargaining and disputes machinery which had been gradually evolving during the century of trade union organization.

Thus, as the United Kingdom emerged from more than a decade of business depression in 1933, the aggregate duration in working days of all disputes in progress during that year fell to the lowest point of any year in the forty for which records are available.4 In I934 the figure dropped still lower. Even during I935 and 1936 , with returning prosperity, the number of working days lost from disputes was less than in any year since I904 except the two (I933 and 1934) previously mentioned and 1928 and 1929 just following passage of the Trade Disputes and Trade Unions Act. Otherwise it was less than in any year for more than four decades. 5 Compare this record with that of the United States where, barring recent years of severe business depression, an almost continuous increase in the number of working days lost from strikes has.taken place in the last decade. ${ }^{6}$ In 1936 , for example, which is the last year. for which comparative figures are obtainable, the number of working days lost from strikes in the United States was seven and one-half times as great as in the United Kingdom while the population of the United States was less than three times that of the latter country.

In a nation where bitter strife between capital and labor and even between rival labor organizations characterizes industrial life, this disputes record of the United Kingdom appears little short of miraculous. How has it been achieved? Though trade union organization, price movements, disputes legislation and economic change have doubtless had their temporary effect, the chief factor in establishing what promises relatively permanent industrial peace in Great Britain has been the gradual development of an extensive system of voluntary collective bargaining supported by statutory machinery for establishing minimum wage rates in which employers and workers participate on a collective bargaining basis. An increasing inclination of employers to negotiate wage increases even involving a rise in real wages and to take the initiative in application of statutory wage-fixing machinery to their industries attests to this fact. Moreover, the tendency of the number of disputes and the number of work people involved to increase disproportionately to the number of working days lost over a period of years leads to the further conclusion that conciliation and

\footnotetext{
317 \& 18 Geo. V, c. 22.

'Ministre of Labour, Annual Report, 1933, p. 83.

- Figures compiled from Ministry of Labour, Annual Reports, 1934-36, and from Ministry of Labour, 2 IST ABstract of Labour Statistics, 1934, p. I25.

'I. L. O., Yearboox of Labour Statistics, 1937, pp. 212-13.
} 
arbitration machinery have also proved instrumental in reducing losses from industrial warfare.

Though the Trade Disputes and Trade Unions Act, 1927, renders illegal any general strike and most sympathetic strikcs as well as those primary strikes whose object extends beyond wages, hours, and/or other conditions of work in a particular trade, the right to strike remains relatively free in Great Britain. ${ }^{7}$ Neither has this legislation nor the registration of trade unions, ${ }^{7 *}$ which is entirely voluntary rather than compulsory as is commonly supposed, curtailed the British workers' freedom to any such extent as is popularly imagined in this country. Distinctly more than to such legal provisions Great Britain's enviable strike record is due to that habit of cooperation between employers and workers resulting from the increasing practice of collective bargaining in its various forms.

\section{Machinery for Dealing with Industrial Disputes}

British machinery for dealing with industrial disputes has four parts: collective agreement, investigation, conciliation, and arbitration. Collective agreement constitutes the foundation upon which efforts to maintain industrial peace are built, investigation, conciliation and, as a last resort, arbitration being applied where collective action fails to prevent disputes.

The roots of the whole system reach back to 1875 when the principle of collective bargaining was first recognized by law. Between this time and the War joint negotiation of wage contracts developed greatly. During the War emergency tribunals of various kinds gave further impetus to democratic procedure in dealing with industrial problems. But not until after the "Whitley Committee Reports" was collective bargaining accepted as fundamental to a government policy designed to promote industrial peace. Anticipating a sudden decline in wages when War contracts ended and returning soldiers glutted the labor market, the Whitley Committee was appointed in $19 \pm 6$ to make recommendations looking towards prevention of industrial conflict. A series of .reports issued in 1917-I8 following nearly two years of study, expressed the conviction that "permanent improvement in relations between employers and employed must be founded upon something other than a cash basis."

Proposing joint participation in the adjustment of industrial matters most affecting the work people, an essential condition of which is adequate organization on both sides, three specific recommendations towards this end were made. These comprised (I) extension of the statutory collective bargaining machinery established by the Trade Boards Act, Igog, to include any trade inadequately organized for voluntary collective bargaining, (2) voluntary establishment of national Joint Industrial Councils, district councils and works committees in well organized industries to

'For details, see Richardson, Industrial Rejations in Great Britain, I.L.O. Studies and Reponts, Series A, No. 36 (1933) 48 et seq.; Millis, The British Trade Disputes and Trade Unions Act, 1927 (1928) 36 J. Por. Econ. 305.

${ }_{72}$ Trade Unions Act, I871, 34 \& 35 Vict. 31, discussed in Rothschild, Government Regulation of Trade Unions in Great Britain (1938) 38 CoL. L. REv. 1, 24-48.

${ }^{8}$ Interim Report on Joint Standing Industriaz. Councils (Match 8, 1917) \$24. 
deal by a similar method with any matters pertaining to their industry, (3) constitution of a standing voluntary arbitration tribunal representative of the two parties to industry and the public to settle disputes which collective bargaining failed to avert. The next few years saw the main features of these proposals adopted. Collective bargaining now forms the bulwark of industrial peace in Great Britain, at least ten and one-half million or 70 per cent of all British industrial and agricultural workers being covered by agreements thus democratically consummated.

Collective bargaining at present takes place in three different forms: statutory, voluntary and quasi-voluntary. Statutory machinery providing for establishment of minimum wage rates by the process of collective bargaining is set up under five Acts of Parliament. These are the Trade Boards Act, Igog, ${ }^{8 *}$ and amending Act, 1918,9 the Coal Mines (Minimum Wage) Act, I9I2, ${ }^{10}$ the Agricultural Wages (Regulation) Act, I924, ${ }^{11}$ applying to England and Wales, and the Agricultural Wages (Regulation) Scotland Act, 1937.12 Nearly three million British workers in the least advantageous economic position fall within the purview of these acts. The distinctive feature common to them all is establishment of permanent boards composed of representatives of labor and employers, for the most part actually engaged in the industry, and one or more persons representing the public. These boards have power to determine minimum rates of wages for their industry, or district in the case of coal mining and agriculture, by a process resembling genuine collective bargaining and are regarded as instruments of self-government. By providing collective bargaining machinery to be used by employers and workers in those industries where organization is not strong enough or where other conditions prevent the making of satisfactory agreements throughout the industry, the government provides the means for placing a floor in the wage structure. A strong foundation for industrial peace is thus laid among workers at the very bottom of the industrial pyramid by the 127 boards operating under these five statutes towards satisfaction of those two basic desires, for purchasing power and for self-government, which give rise to industrial conflict.

Though coal mining has for many years been the storm center of industrial strife owing to peculiar circumstances with which even strong labor organization is unable to cope, only three or four strikes have ever been called in an industry having a Trade or Agricultural Board. Even if these lowest-paid, poorest-organized workers are in a weak position for striking, the fact that they are guaranteed participation in establishing satisfactory standards for themselves tends to create a good feeling that leavens the lump, whereas inarticulate unrest would almost surely find expression among allied workers with the power to strike.

Application of the same principle to the prevention of conflict in well-organized industries is provided on a voluntary basis through the Whitley Council scheme. In

\footnotetext{
84 9 EDw. VII, c. 22.

8 \& 9 GEo. V, c. 32.

14 \& 15 GEO. V, c. 37 .
}

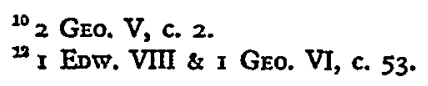


accordance with the second recommendation of the Whitley Committee, noted above, a system of shop committees, district committees and national Joint Industrial Councils now exist in some 64 industries, services or branches thereof, including approximately one-fifth of all occupied persons, or about three million individuals. These councils are voluntary, standing, bi-partite and completely autonomous bodies. They have proved especially successful in public service and in highly localized industries of intermediate size and degree of organization. The government has no statutory power to establish these Whitley Councils, as the national Joint Industrial Councils are called, but the Ministry of Labor has encouraged their organization by preparing a model constitution, recognizing them as the official consultative committees on matters pertaining to their industry, and appointing a liaison officer to assist the Councils as they may request.

Most of the Whitley Councils have dealt with wages and hours and some with cognate subjects as well. Agreements being binding only upon the firms voluntarily belonging to a Council, they are neither applicable to the entire trade nor legally enforceable as are the decisions of Trade and Agricultural Boards. Yet like these boards, the existence of Councils has promoted organization of both workers and employers, at the same time enhancing their influence. Though unable to prevent the general strike in 1926, the Whitley Councils emerged from that cataclysm sufficiently strong to provide a forum for reasonable discussion of the serious issues arising out of the strike. Many of the Councils at that time added provisions to their constitutions insuring an interval of discussion and negotiation before a stoppage of work should in future occur. ${ }^{13}$ Aside from the general strike, no major dispute has occurred in a Whitley Council industry. By rendering regular discussion and negotiation concerning wages and other matters possible in industries where this had not been previously customary, the Whitley Councils have created a mutual understanding between the two parties to industry and a satisfaction in work which has contributed materially towards industrial peace.

The larger and most highly organized industries, however, like coal mining, cotton manufacture, railway transport, engineering, iron and steel, shipbuilding, etc., never established Whitley Councils. They have their own peculiar negotiating machinery or, in the case of cotton manufacture, are the subject of special legislation. As far back as rg2o several of the Whitley Councils recommended that wage agreements reached by their members should be made binding upon the entire trade by statutory action. But it was not until 1934 that the "depressed" cotton textile industry was thus proteced from wage under-cutting by embodiment of this principle in the Cotton Manufacturing Industry (Temporary Provisions) Act, ${ }^{14}$ which represents the quasi-voluntary or third type of statutory collective bargaining machinery. Under specified circumstances this Act provides that voluntary agreements made by a majority of the workers and by employers controlling a majority of the looms may

\footnotetext{
${ }^{2}$ Ministry of Labodr, AnnUai. Report, 1926, p. 8.
}

${ }_{24} \& 25$ Gro. V, c. 30. 
upon approval of the Minister of Labour become legally applicable to all employees of those grades in the industry.

In addition to this statutory, voluntary and quasi-voluntary machinery designed to prevent occurrence of disputes by providing for collective bargaining, statutory, voluntary and quasi-voluntary machinery directed at settlement of disputes once they have taken place, also exists.

The first legislation of this nature was the Conciliation Act, $1896,{ }^{15}$ passed as a result of the recommendations made by a Royal Commission appointed after the great dock strike of 1889 . This Act provides for voluntary conciliation by authorizing the Board of Trade (since rgı6, the Ministry of Labour) to inquire into any difference or to take steps towards bringing the parties together. On the request of either party, the Minister may appoint a conciliator to assist in securing a settlement or, with the consent of both parties to the dispute, he may appoint an arbitrator to settle the difference. ${ }^{16}$ Somewhat strengthened by an amendment in 1908 providing for Courts of Arbitration to be appointed as required from panels of employer and worker representatives and of chairmen. This act remains in operation but is seldom applied since the Industrial Courts Act ${ }^{17}$ was passed in rgig.

During the War the government was forced to abandon its traditional industrial policy of non-interference and voluntary procedure in industrial conflict. By the Munitions of War Act, $x 915,{ }^{18}$ and succeeding acts the principle of compulsion was applied, strikes and lockouts being prohibited in certain industries. The awards of various tribunals temporarily set up to deal with matters affecting production of war materials classified as "munitions" were thade binding. Though some of the larger industries like mining, rail transport and cotton textile did not fall within the purview of these acts, their scope was wide, and in some cases awards could be extended to cover the whole of a trade or industry where a dispute arose. The Committee on Production, which constituted the chief arbitration tribunal during the War period, gained great prestige throughout the country. More than half of all disputes occurring between I9I4-18 came before it, nearly 8,000 awards being issued in the years I915-18. But strikes were not entirely quelled even with these compulsory measures.

At the end of the War, employers, labor 'and the government agreed to discontinue the policy of compulsion. In response to the third recommendation of the Whitley Committee, previously stated, a permanent Industrial Court was established to settle disputes on a voluntary basis. Besides vesting the Ministry of Labour with powers of conciliation and arbitration similar to those contained in the Act of 1896 , the Industrial Courts Act also provides for the establishment of a permanent Indus trial Court and for ad hoc Courts of Enquiry to which the Minister of Labour may refer a dispute on occasion. Before taking such action, however, it is provided that the voluntary joint machinery set up in organized industries shall have been used

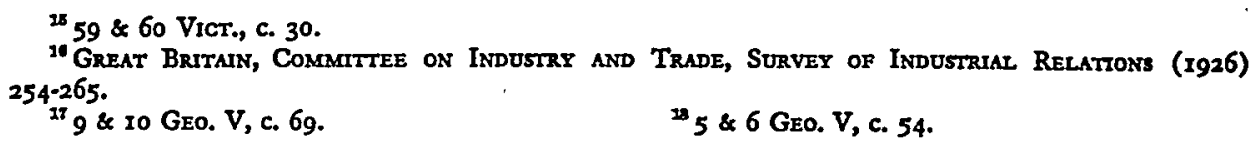


to the fullest extent. Only when such action has failed to effect a settlement may the Minister with the consent of both parties, refer the dispute to arbitration by the Industrial Court, by one or more individual arbitrators or by an ad hoc Board of Arbitration composed of representatives of employers, workers and an independent chairman as provided by the Act of 1908 .

The Industrial Court is another tri-partite body, the President and the Chairman being impartial persons. The Act also stipulates that there must be women members. The Court's awards are not compulsory but are usually accepted by the parties concerned. The number of cases dealt with by the Court has not been large except in the years immediately following the War when it disposed of cases not yet handled by War tribunals. The tendency is for the number of cases to decline and largely to comprise disputes in public service industries like electricity supply and road traffic which by statute come within its aegis. In 1936 the Court dealt with 35 cases, making a total of $\mathrm{x}, 67 \mathrm{I}$ awards since $1919 .{ }^{19}$ There is little doubt that the Industrial Court has fallen short of the great expectations originally held of it. More than to anything else this is probably due to a deep-seated distrust of arbitration prevalent among British people. The chief value of the Court lies in the development of principles and techniques connected with settlement of disputes which its permanent nature renders possible.

Quite separate from the Industrial Court is the Civil Service Arbitration Tribunal which is similarly constituted. The government has definitely accepted the principle of arbitration for the civil service. This body deals with claims affecting the emoluments, weekly hours of work and leave of classes of civil servants, individual cases being excluded.

The Courts of Enquiry provided for in the Industrial Courts Act, Part 2, thay consist of one or more persons. Irrespective of a dispute having been reported to him, the Minister of Labour may upon his own initiative appoint such a Court to investigate and report on the matter. Reports must be immediately laid before both Houses of Parliament and may be published by the Minister of Labour. In this way Parliament, the persons concerned and the public are insured a fair appraisal of the facts and issues involved in a dispute of importance. The Minister has, however, seldom used his power to appoint Courts of Enquiry, in general reserving its force for disputes seriously affecting the public interest. Such action is regarded as a last resort to be used when no recognized method of settlement seems possible.

Behind this statutory legislation as a defense against industrial war, lies the vast network of committees, boards and tribunals of various kinds established voluntarily by workers and employers in nearly every organized industry to suit its peculiar conditions and needs. Among those industries having the most highly developed and most effective conciliation and arbitration machinery of this type are iron and steel, engineering, boot and shoe and the building trades.

In addition there is the quasi-voluntary machinery operating in several important

19 Ministry of Labour, Annual Report, r936, p. 73. 
industries, e.g., coal mining and rail transport. Notwithstanding the elaborate voluntary machinery for negotiation and settlement of disputes existing in the coal mining industry since I870 and also the minimum wage legislation of rgr2, their local character, together with the breakdown of national agreements after the prolonged strike of 1926, rendered more effective national machinery advisable. Under the Coal Mines Act, $1930,{ }^{20}$ a Coal Mines National Industrial Board was constituted to meet this need. This Board was to consist of seventeen members, including eight members representing the various organizations on each side and an impartial chairman who should investigate and report to the owners and workers in any district concerning a dispute referred to them. Owing to the necessity for appointing unofficial persons to this Board on account of the refusal of the employers' organizations to suggest names, its authority has been distinctly weakened, though it has nevertheless conducted inquiries into a number of disputes.

Because of the public nature of the service supplied by railways special legislation has also been applied there. Part IV of the Railways Act, Ig2r, ${ }^{21}$ gave statutory effect to negotiating machinery then operating between the parties concerned. Apparently on account of the unwieldy character of this machinery it was replaced in February, I935 by a new set-up at the instigation of the four main line railway companies. The present machinery consists of a hierarchy of railway staff councils established for negotiatory purposes, at the top of which is the Railway Staff National Tribunal. This is an ad hoc body composed of three members, including one from each side and a third selected by these two, to which issues involving "interpretation" as distinguished from "application" of a national agreement are to be referred when not settled by the larger bi-partite Railway Staff Council, next below it in authority. ${ }^{22}$

Also of great importance is the work of the expert conciliation officers of the Ministry of Labour who continuously and quietly keep in touch with the state of industrial relations through six local offices, reporting major difficulties to headquarters in London and dealing on the spot with minor disputes, both incipient and active, in the various industrial areas. The services of these conciliators is at the disposal of both employers and employees in connection with such matters as improvement of joint machinery, prevention or settlement of disputes or any problem relating to the mutual relations of workers and employers.

The Ministry of Labour also acts as the central authority through which the elaborate machinery for collective bargaining and settlement of disputes is coordinated. But the coordination is loose. For non-intervention is the long-established policy of this department. The first approach to industrial peace is voluntary agreement regarding possible matters of dispute such as wages and hours, and the last recourse is reference of a dispute to the Industrial Court for award, but only with the consent of both parties, inquiry by a Court on the Minister's own initiative being held in reserve for those cases impinging strongly upon the public welfare. That the

${ }^{2} 20$ \& 2I Geo. V, c. 34.

I2 II \& I2 GEO. V, c. 55.

${ }^{2}$ Ministry of Labour Gazette, March 1935, p. 89. 
present record of industrial peace can be achieved in view of this preeminently voluntary system is due, on the one hand, to a high degree of responsibility among employers and workers which the system itself has developed over a long period of years and, on the other, to the attitude of friendly adviser to both parties in industry which the Ministry of Labour maintains in the interests of the country as a whole.

\section{Principles Embodied in the British Disputes Machinery}

Implicit in the handling of industrial conflict in Great Britain are certain basic principles essential to its effectiveness and suggestive of a constructive approach to that problem wherever it exists. The basic assumption upon which the entire structure rests is that the power to govern himself whether at home or at work is as essential to the psychological health of every human being, employer or employee, as the power to buy adequate food, clothing and shelter is to his physical well-being. Men and women do not work for money alone. They work also for the sake of achieving a certain self-mastery which may become a conscious objective only when it is denied. Therefore, the industry in which a person works becomes the means, cooperation with others engaged in it the method, to the achievement of both ends. And it is in the effort, often the unconscious effort, towards realization of a bigger selfhood as well as in the struggle for daily bread that industrial conflict most often arises.

With that sure British instinct for government, economic democracy operating from the bottom up through collective bargaining. rather than from the top down through government fiat has in recognition of these human facts been established as the key to industrial peace. Preventive measures are regarded as more important than remedial: voluntary action has been chosen in preference to compulsory; conciliation takes precedence over arbitration; development of a spontaneously responsible unionism is found safer than compulsory registration or suppression of workers' organizations; and a flexible hodgepodge of committees, boards, tribunals and laws suited to the special conditions existing in individual industries a more satisfactory path to industrial good will than neat but mechanical uniformity. In any case the test of the pudding is in the eating. And the British enjoy a high degree of industrial friendliness and peace. Perhaps it is for us in the United States consciously to adapt to our peculiar industrial situation, those methods developed by British genius with such patient persistence. 